\title{
Geologic Disposal of HEU Aluminum-Based DOE Fuels
}

J. Wesley Davis, Framatome Cogema Fuels and

Dr. Peter Gottlieb, TRW

Civilian Radioactive Waste Management System, Management and Operating Contractor 1180 Town Center Drive

Las Vegas, NV 89134

$(702) 295-4557 /(702) 295-4381$

\section{Introduction}

This paper describes the disposal criticality analysis for canisters containing highly enriched uranium (HEU) in the form of aluminum-based Department of Energy spent nuclear fuel (DOESNF) within a Codisposal Waste Package also containing 5 vitrified high level waste (HLW) canisters ${ }^{1}$. Figure 1 shows the configuration within the codisposal waste package after emplacement in the repository. Massachusetts Institute of Technology (MTT) U-Al fuel with 93.5\% enriched uranium was designated as representative of the HEU inventory at Savannah River Site. A canister basket design accomodating 64 MIT assemblies (16/layer, 4 layers) totaling $35.2 \mathrm{~kg}$ of uranium was developed for this fuel type. Gadolinium phosphate $\left(\mathrm{GdPO}_{4}\right)$ distributed on or in carbon steel plates was incorporated into a carbon steel internal basket structure. The basket structure is contained within a $439 \mathrm{~mm}$ OD, $15 \mathrm{~mm}$ thick XM-19 shell to form the DOE-SNF canister. 


\section{Approach}

The general disposal criticality analysis methodology described in a separate paper was applied with the following sequences unique to the Codisposal Waste Package in general, and the Albased fuel in particular: 1) aqueous corrosion of stainless steel HLW and fuel containers; 2) degradation of HLW glass to clay; 3) degradation of Al-based fuel concurrent with or after the HLW glass; and 4) degradation of DOE-SNF canister basket materials including criticality control material coupled with flushing of soluble compounds from the waste package.

The chemistry/geochemistry of the system was analyzed using the EQ3/6 program². Parametric criticality calculations were run on a range of possible distributions of fuel within the waste package using $\mathrm{MCNP}^{3}$ to identify the most reactive configurations and to determine the minimum amount of neutron absorber required to be distributed with the fuel in its degraded configurations.

\section{Results}

The aluminum-based fuel would be expected to degrade through oxidation within a few decades to a few centuries of the fuel canister breach. If the fuel canister were penetrated while the HLW glass was degrading, the chemistry (primarily $\mathrm{pH}>10.0$ ) would be such that most of the uranium could dissolve. This scenario would not be a criticality concern inside the waste package because of the low uranium concentration in solution and the presence of the large boron inventory within the HLW glass'.

Should the DOE-SNF canister be penetrated after the HLW glass was completely degraded then 
the $\mathrm{pH}$ would be near neutral, and the uranium would no longer be soluble so it would remain in the canister or waste package'. Three configurations could result based on level of degradation of the other components and the location of the canister as it degraded within the waste package: 1) degraded (oxidized) fuel material distributed within the DOE-SNF canister; 2) layers of hydrated aluminum, uranium, and iron oxides from the degraded DOE-SNF canister above the degraded HLW (clay); and 3) degraded products from the fuel mixed with various fractions of the degraded HLW. The volume fraction of water in the degraded HLW and fuel, as well as the mass of iron oxide from the degraded canisters and basket, were varied in parametric criticality calculations. The bounding analysis of separation mechanisms indicates that no more than $14 \%$ of the iron and $\mathrm{GdPO}_{4}$ could be separated from the fuel as long as the basket and absorber plates degrade before the canister significantly corrodes away ${ }^{1}$. Based on theoretical analysis and on a review of literature on natural deposits, the small differences in density and particle size distribution between uranium bearing minerals, iron oxide, and the $\mathrm{GdPO}_{4}$ particulates will not result in significant stratification.

The most reactive degraded fuel mixture occurs in configuration 1 and requires $1.25 \mathrm{~kg}$ of Gd to be distributed in carbon steel plates in the intact canister basket ${ }^{1}$. After degradation of the carbon steel basket, the geochemistry analysis indicates that $1.1 \mathrm{~kg}$ of Gd would remain mixed with the fuel, while MCNP calculations indicate that less than $0.11 \mathrm{~kg}$ of Gd would be required to fall below the upper subcritical limit (USL) ${ }^{1}$.

Analysis of configurations 2 and 3, which occur after the DOE-SNF canister is severely degraded, indicate less than $0.01 \mathrm{~kg} \mathrm{Gd}$ is required to meet the USL if credit is taken for the iron 
oxide produced from the degradation of the carbon steel basket structure and DOE-SNF canister shell'.

\section{Conclusions}

Without the presence of a very insoluble neutron absorber in the canisters of the HEU Al-based DOE-SNF, the long-term action of infiltrating water can lead to a small, but significant, probability of criticality. The MIT fuel canister design with $1.25 \mathrm{~kg}$ of $\mathrm{Gd}$ (as $\mathrm{GdPO}_{4}$ ) distributed in or on carbon steel absorber plates throughout the carbon steel basket will reduce the probability of criticality to virtually zero during the first several hundred thousand years following emplacement.

\section{Acknowledgement}

This work was supported by the Department of Energy through the Westinghouse Savannah River Company, Savannah River Site (Contract Number DE-AC01-91RW00134).

\section{References}

1. Disposal Criticality Analysis for Aluminum-Based Fuel in a Codisposal Waste Package ORR and MIT SNF - Phase II, DI Number: BBA000000-01717-0200-00060 REV 00, CRWMS M\&O, December 1997.

2. Wolery, Thomas J., EQ3/6, A Software Package for Geochemical Modeling of Aqueous Systems: Package Overview and Installation Guide (Version 7.0), UCRL-MA-1 10662 PT I, LLNL, 1992. 
3. Briesmeister, Judith F., Editor, MCNP - A General Monte Carlo N-Particle Transport Code, Version 4A, LA-12625-M, LANL, November 1993. 


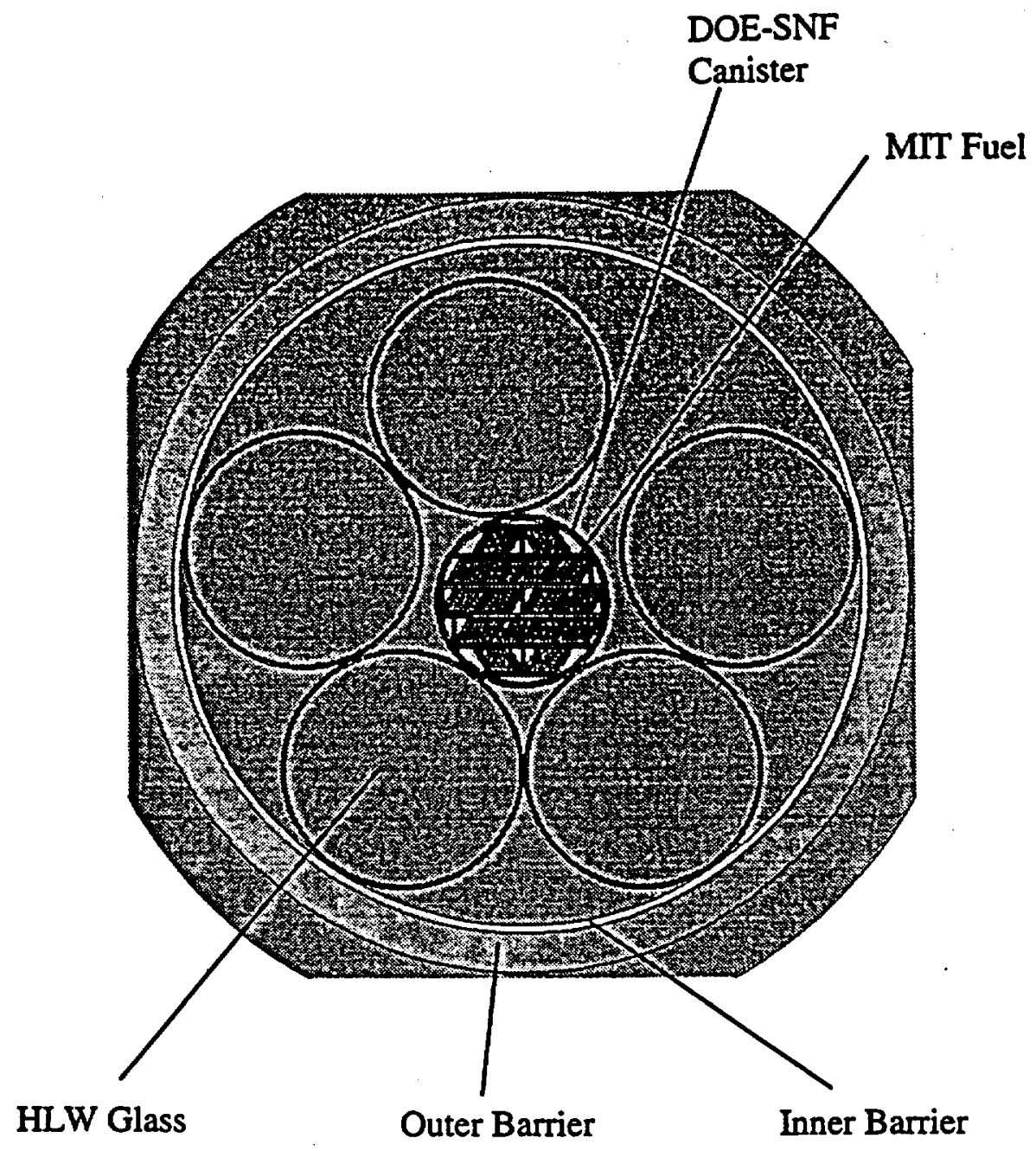

Figure 1. Codisposal Waste Package with a MIT SNF Canister 